\title{
Uncertainties Associated with the Definition of a Hydrologic Source Term for the Nevada Test Site
}

\author{
David K. Smith \\ Bradley K. Esser \\ Isotope Sciences Division \\ Lawrence Livermore National Laboratory \\ Livermore, CA 94550 \\ Joseph L. Thompson \\ Chemical Sciences and Technology \\ Los Alamos National Laboratory \\ Los Alamos, NM 87545
}

May 1995

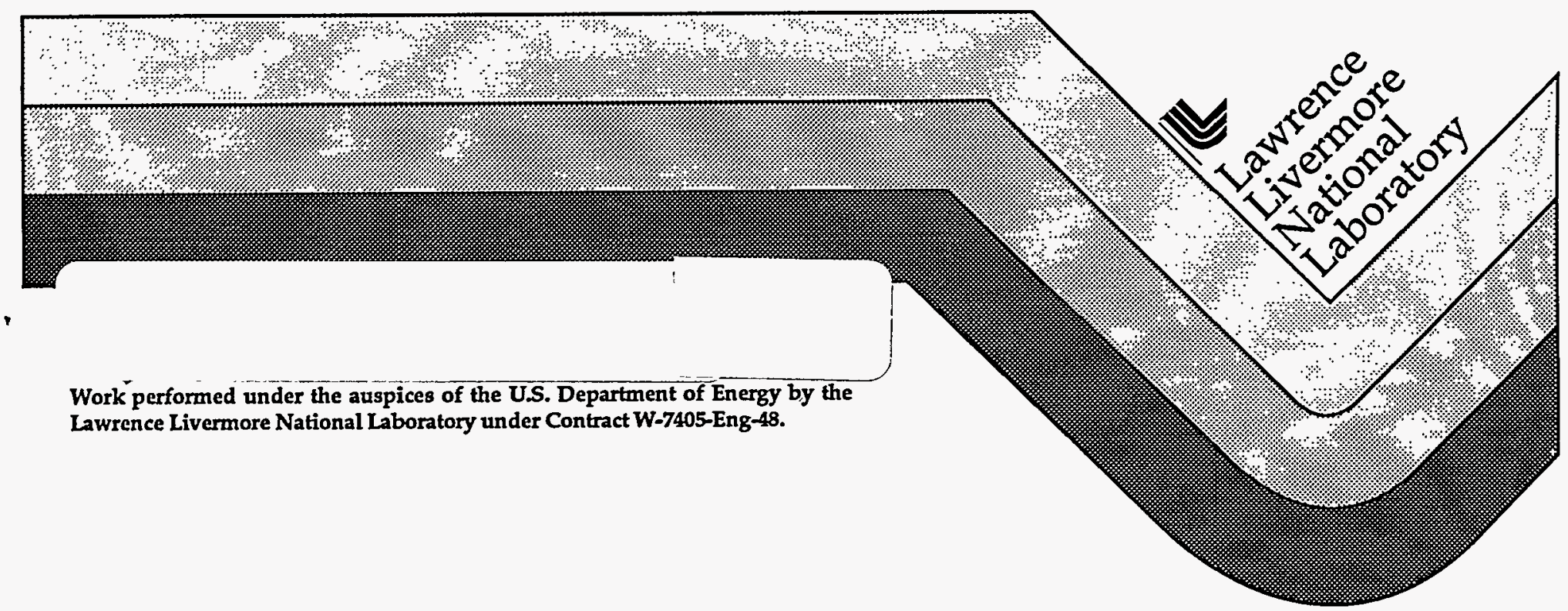




\section{DISCLAIMER}

This document was prepared as an account of work sponsored by an agency of the United States Government. Neither the United States Government nor the University of California nor any of their employees, makes any warranty, express or implied, or assumes any legal liability or responsibility for the accuracy, completeness, or usefulness of any information, apparatus, product, or process disclosed, or represents that its use would not infringe privately owned rights. Reference herein to any specific commercial products, process, or service by trade name, trademark, manufacturer, or otherwise, does not necessarily constitute or imply its endorsement, recommendation, or favoring by the United States Government or the University of California. The views and opinions of authors expressed herein do not necessarily state or reflect those of the United States Government or the University of California, and shall not be used for advertising or product endorsement purposes.

This report has been reproduced directly from the best available copy.

Available to DOE and DOE contractors from the Office of Scientific and Technical Information

P.O. Box 62, Oak Ridge, TN 37831

Prices available from (615) 576-8401

Available to the public from the

National Technical Information Service

U.S. Department of Commerce 5285 Port Royal Rd. Springfield, VA 22161 


\section{DISCLAIMER}

Portions of this document may be illegible in electronic image products. Images are produced from the best available original document. 


\section{EXECUTIVE SUMMARY}

The U.S. Department of Energy, Nevada Operations Office (DOE/NV), Environmental Restoration Division is seeking to evaluate groundwater contamination resulting from 30 years of underground nuclear testing at the Nevada Test Site (NTS). This evaluation requires knowledge about what radioactive materials are in the groundwater and how they are transported through the underground environment. This information coupled with models of groundwater flow (flow paths and flow rates) will enable predictions of the arrival of each radionuclide at a selected receptor site. Risk assessment models will then be used to calculate the expected environmental and human doses.

The accuracy of our predictions depends on the validity of our hydrologic and risk assessment models and on the quality of the data for radionuclide concentrations in ground water at each underground nuclear test site. This paper summarizes what we currently know about radioactive material in NTS groundwater and suggests how we can best use our limited knowledge to proceed with initial modeling efforts.

The amount of a radionuclide available for transport in groundwater at the site of an underground nuclear test is called the hydrologic source term. The radiologic source term is the total amount of residual radionuclides remaining after an underground nuclear test. The hydrologic source-term is smaller than the radiologic source term because some or most of the radionuclide residual cannot be transported by groundwater. The radiologic source term has been determined for each of the underground nuclear tests fired at the NTS; however, the hydrologic source term has been estimated from measurements at only a few sites. Laboratory studies have shown that radioactive residues from nuclear tests leach very slowly out of the melt debris formed in the explosion cavity. Many dissolved radionuclides sorb quite strongly on zeolites incorporated in the volcanics of the NTS, and hence do not move with groundwater. Thus for many radionuclides only a small fraction can be expected to move away from the cavity/chimney region where they were deposited at the time of the nuclear explosion; a few field observations confirm this expectation. There are a few radionuclides, however, which are produced in forms which are almost completely mobile in groundwater. Tritium (as tritiated water), $85 \mathrm{Kr}$ and radionuclides forming negative ions (e.g. ${ }^{36} \mathrm{Cl},{ }^{129} \mathrm{I},{ }^{99} \mathrm{Tc}$ and ${ }^{125} \mathrm{Sb}$ ) are in this category. Such materials may serve as conservative tracers of groundwater flow because they do not interact with the rock through which they move.

In order to directly measure the hydrologic source terms it would be necessary to sample the water from the cavity/chimney regions at each test site. Such measurements are technically very challenging, very expensive and, as such, have been done only in a few cases. The alternative is to estimate hydrologic 
source terms based on calculated source terms, but important gaps in the present state of knowledge makes these estimations very uncertain. The DOE/NV is aggressively pursuing a plan (DOE, 1995) which will permit estimated hydrologic source terms to be checked against field measurements at locations representative of particular hydrogeologic environments at the NTS. In the meantime, it is necessary to proceed with a modeling effort based on present knowledge.

The authors recommend that the first round of transport modeling utilize a tritium-only source term. In or near the saturated zone, tritium is the radionuclide present in the largest concentration of any radioactive species for 100-200 years post-test. Because $99.9 \%$ of the tritium produced from an underground nuclear explosion is incorporated in the water molecule as HTO, the hydrologic source term is the same as the radiologic source term for the saturated zone. Tritium is a conservative tracer ideal for modeling groundwater flow. For at least 100 years, all other radionuclides will be transported to down-gradient receptor in much lower concentrations than tritium. For these reasons, we believe that tritium is the only radionuclide contaminant from nuclear testing which can be presently modeled with confidence. In concert with modeling the tritium-only source term, field and laboratory studies which yield the data necessary to expand the model to other radionuclides must be undertaken. Other radionuclide species, notably $\mathrm{Pu}$, although present in lower abundance than tritium, may have higher toxicities in groundwater on a per volume basis and must also be evaluated critically. The considerations which support our recommendations follow. 


\section{INTRODUCTION}

The U.S. Department of Energy, Nevada Operations Office (DOE/NV), is investigating subsurface contamination residual from 828 underground nuclear weapons test conducted from 1955 tö 1992 at the Nevada Test Site, Nye County, Nevada. The Underground Test Area (UGTA) Operable Unit was established by DOE/NV to identify, characterize and potentially remediate groundwater impacted by testing. The objective is to provide a measure of potential risk to human health and the environment from impacted groundwaters as well as return information that can support sound management decisions regarding proposed remediation. This process is expected to take many years and is being approached in a phased manner. The first phase relies primarily on existing data, is preliminary, and will assist in planning and prioritizing objectives for the remainder of the project.

An accurate assessment of the total radionuclide inventory present at the Nevada Test Site includes all radioactive species produced by or remaining after underground nuclear explosions at the Nevada Test Site during the period 1955 to 1992 . An inventory for 57 radionuclides, with half lives in excess of ten years, has been compiled for each of the experiments fired beneath the Nevada Test Site (Goishi et al., 1994). The inventory includes those radionuclides available for potential dispersal away from test centers and provides an estimate of the quantity of radionuclides underground at the NTS. However, not all radionulides are equally available for transport: This is an important observation because the numerical models of groundwater flow and contaminant transport should be initiated with the amount of contamination available for transport. A necessary distinction must be drawn between the radiologic source term which includes all radioactive material remaining after a nuclear test, and the hydrologic source term which includes only that radioactive material dissolved in or available for transport by groundwater. The radionuclide inventory reported by Goishi et al. (1994) represents the radiologic source term and does not represent the amount of radioactivity that is or ever will be dissolved in groundwater at NTS. Because different radioactive species are not equally available for solution and transport, the hydrologic source term is considerably less than the total radiologic source term.

A comprehensive transport model requires an inventory of radionuclide species mobile in groundwater which includes 1) tritium, 2) conservative anions and neutral species such as ${ }^{85} \mathrm{Kr},{ }^{99} \mathrm{Tc},{ }^{106} \mathrm{Ru},{ }^{36} \mathrm{Cl}$ and ${ }^{129} \mathrm{I}$ and 3 ) less conservative cationic species including ${ }^{90} \mathrm{Sr},{ }^{137} \mathrm{Cs},{ }^{125} \mathrm{Sb},{ }^{60} \mathrm{Co},{ }^{95} \mathrm{Zr},{ }^{235} \mathrm{U}$, ${ }^{239} \mathrm{Pu}$ and others.

The following sections detail some of the limitations of estimating both the radiologic source term and the hydrologic source term. 


\section{LIMITATIONS OF THE RADIOLOGIC SOURCE TERM}

The radionuclide inventory for the Nevada Test Site has been compiled by the Lawrence Livermore and Los Alamos National Laboratories (Goishi et al., 1994). Radionuclides included in the source term inventory are: 1) residual fissile fuel and tracer materials, such as $U$ isotopes, $\mathrm{Pu}$ isotopes, $\mathrm{Am}$, and ${ }^{244} \mathrm{Cm}$; 2) fission products such as ${ }^{137} \mathrm{Cs}$ and $\left.{ }^{90} \mathrm{Sr} ; 3\right)$ tritium $\left({ }^{3} \mathrm{H}\right)$ and 4$)$ activation products induced by neutron capture by device parts, external hardware, and the surrounding geologic medium such as ${ }^{14} \mathrm{C},{ }^{36} \mathrm{Cl}$, and ${ }^{41} \mathrm{Ca}$. Radionuclides were excluded from the inventory if they were produced in such low amounts that if the total amount produced during a nuclear test were dissolved into a volume of water equal to the volume of the detonation cavity for the event and allowed to decay for 100 years the resulting aqueous concentration would be less than one-tenth of the maximum permissible concentration (MPC). MPCs proposed for drinking water by the U.S. Environmental Protection Agency (EPA) are listed in the Federal Register (vol. 56, no. 138, July 18, 1991). MPC's are listed in $\mu \mathrm{Ci} / \mathrm{ml}$; $\mathrm{a} \mu \mathrm{Ci}$ is $2.22 \times 10^{6}$ disintegrations per minute. For nuclides with no listed MPC, Goishi et al. (1994) conservatively assumed a value of $10^{-8} \mu \mathrm{Ci} / \mathrm{mL}$. The MPC of a nuclide listed in the EPA compilation is that concentration in drinking water which will impart a dose of $4 \mathrm{mrem} /$ year to a person drinking an average of 2 liters of water per day. This criterion effectively excludes almost all radionuclides with half-lives less than ten years some of which $\left(65 \mathrm{Zn},{ }^{106} \mathrm{Ru}\right)$ are produced in great abundance in a nuclear event. Many of these nuclides have halflives so short (microseconds to hours) that they have decayed to undetectable levels soon after zero (firing) time. Others are more stable, soluble and potentially could be transported by groundwater during time intervals less than 100 years. Although important in the context of near-field migration, these shorter lived species are omitted from the Goishi et al. (1994) inventory. Table $I$ is a list of radionuclides important for investigations of transport and modeling; it includes both long and short lived radionuclides.

\section{TABLE I}

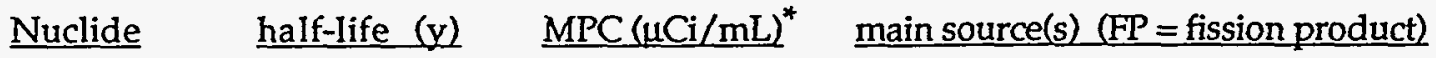

$\begin{array}{cccl}{ }^{3} \mathrm{H} & 12.3 & 6.1 \times 10^{-5} & \text { device comp.; }{ }^{6 \mathrm{Li}(n, \alpha) \mathrm{T}} \\ { }^{10} \mathrm{Be} & 1.6 \times 10^{6} & - & { }^{10} \mathrm{~B}(\mathrm{n}, \mathrm{p}) ;{ }^{9} \mathrm{Be}(\mathrm{n}, \gamma) \\ { }^{14} \mathrm{C} & 5730 & 3.2 \times 10^{-6} & { }^{14} \mathrm{~N}(\mathrm{n}, \mathrm{p}) ;{ }^{13} \mathrm{C}(\mathrm{n}, \mathrm{g}) ; 17 \mathrm{O}(\mathrm{n}, \alpha) \\ { }^{22} \mathrm{Na}{ }^{* *} & 2.605 & 4.66 \times 10^{-4} & { }^{23} \mathrm{Na}(\mathrm{n}, 2 \mathrm{n}) \\ { }^{26} \mathrm{Al} & 7.3 \times 10^{5} & - & { }^{27} \mathrm{Al}(\mathrm{n}, 2 \mathrm{n}) \\ { }^{36} \mathrm{Cl} & 3.01 \times 10^{5} & 1.8 \times 10^{-6} & { }^{35} \mathrm{Cl}(\mathrm{n}, \gamma) ;{ }^{39} \mathrm{~K}(\mathrm{n}, \alpha) \\ { }^{39} \mathrm{Ar} & 269 & - & 39 \mathrm{~K}(\mathrm{n}, \mathrm{p}) ;{ }^{38} \mathrm{Ar}(\mathrm{n}, \gamma)\end{array}$




\begin{tabular}{|c|c|c|c|}
\hline${ }^{41} \mathrm{Ca}$ & $1.03 \times 10^{5}$ & - & ${ }^{40} \mathrm{Ca}(n, \gamma)$ \\
\hline $53_{\mathrm{Mn}}$ & $3.7 \times 10^{6}$ & - & ${ }^{54} \mathrm{Fe}(n, 2 n){ }^{53} \mathrm{Fe} \Rightarrow{ }^{53} \mathrm{Mn}$ \\
\hline${ }^{59} \mathrm{Ni}$ & $7.6 \times 10^{4}$ & $2.7 \times 10^{-5}$ & ${ }^{58} \mathrm{Ni}(n, \gamma)$ \\
\hline${ }^{60} \mathrm{Co}^{* *}$ & 5.271 & $2.2 \times 10^{-4}$ & ${ }^{59} \mathrm{Co}(n, \gamma)$ \\
\hline $63 \mathrm{Ni}$ & 100 & $9.9 \times 10^{-6}$ & ${ }^{62} \mathrm{Ni}(n, \gamma),{ }^{64} \mathrm{Ni}(n, 2 n),{ }^{63} \mathrm{Cu}(\mathrm{n}, \mathrm{p})$ \\
\hline $65 \mathrm{Zn}^{* *}$ & 0.66 & $3.96 \times 10^{-4}$ & ${ }^{64} \mathrm{Zn}(\mathrm{n}, \gamma)$ \\
\hline${ }^{79} \mathrm{Se}$ & $\leq 6.5 \times 10^{4}$ & - & ${ }^{78} \mathrm{Se}(n, \gamma) ;{ }^{79} \mathrm{Br}(n, p)$ \\
\hline $81_{\mathrm{Kr}}$ & $2.1 \times 10^{5}$ & - & ${ }^{80} \mathrm{Kr}(\mathrm{n}, \gamma) ; 81_{\mathrm{Br}}(\mathrm{n}, \mathrm{p})$ \\
\hline${ }^{85} \mathrm{Kr}$ & 10.7 & - & $\mathrm{FP} ;{ }^{84} \mathrm{Kr}(\mathrm{n}, \gamma)$ \\
\hline $90 \mathrm{Sr}$ & 29.1 & $4.2 \times 10^{-8}$ & FP \\
\hline${ }^{93} \mathrm{Zr}$ & $15 \times 10^{6}$ & $5.1 \times 10^{-6}$ & $\mathrm{FP} ;{ }^{92} \mathrm{Zr}(\mathrm{n}, \gamma) ;{ }^{44} \mathrm{Zr}(\mathrm{n}, 2 \mathrm{n})$ \\
\hline $92 \mathrm{gNb}$ & $3.6 \times 10^{7}$ & - & ${ }^{92} \mathrm{Mo}(\mathrm{n}, \mathrm{p}) ;{ }^{9} \mathrm{Nb}(\mathrm{n}, 2 \mathrm{n})$ \\
\hline $93 \mathrm{~m}_{\mathrm{Nb}}$ & 16.1 & $1.0 \times 10^{-5}$ & ${ }^{93} \mathrm{Nb}\left(n, n^{\prime}\right)$ \\
\hline${ }^{94} \mathrm{Nb}$ & $2.0 \times 10^{4}$ & $7.1 \times 10^{-7}$ & $\mathrm{FP} ;{ }^{93} \mathrm{Nb}(\mathrm{n}, \gamma)$ \\
\hline${ }^{93} \mathrm{Mo}$ & $\sim 3500$ & - & ${ }^{92} \mathrm{Mo}(n, \gamma)$ \\
\hline${ }^{98} \mathrm{Tc}$ & $4.2 \times 10^{6}$ & - & ${ }^{98} \mathrm{Ru}(\mathrm{n}, \mathrm{p})$ \\
\hline${ }^{99} \mathrm{gTc}$ & $2.13 \times 10^{5}$ & $3.8 \times 10^{-6}$ & $\mathrm{FP} ;{ }^{99} \mathrm{Ru}(\mathrm{n}, \mathrm{p})$ \\
\hline${ }^{106} \mathrm{Ru}^{* *}$ & 1.020 & $2.0 \times 10^{-4}$ & FP \\
\hline${ }^{107} \mathrm{Pd}$ & $6.5 \times 10^{6}$ & $3.7 \times 10^{-5}$ & $\mathrm{FP} ;{ }^{106} \mathrm{Pd}(\mathrm{n}, \gamma)$ \\
\hline $113 m_{C d}$ & 14.1 & - & $\mathrm{FP}$ \\
\hline $121 \mathrm{~m}_{\mathrm{Sn}}$ & $\sim 55$ & $2.3 \times 10^{-6}$ & $\mathrm{FP} ;{ }^{120} \mathrm{Sn}(\mathrm{n}, \gamma)$ \\
\hline $125 \mathrm{Sb}^{* *}$ & 2.758 & $1.94 \times 10^{-3}$ & FP \\
\hline $126 \mathrm{Sn}$ & $-1.0 \times 10^{5}$ & $2.9 \times 10^{-7}$ & FP \\
\hline${ }^{129} \mathrm{I}$ & $1.57 \times 10^{7}$ & $2.1 \times 10^{-8}$ & $F P ;{ }^{129} \mathrm{Xe}(n, p)$ \\
\hline${ }^{134} \mathrm{Cs}^{* *}$ & 2.065 & $8.1 \times 10^{-5}$ & FP \\
\hline${ }^{135} \mathrm{Cs}$ & $2.3 \times 10^{6}$ & $7.9 \times 10^{-7}$ & FP \\
\hline${ }^{137} \mathrm{Cs}$ & 30.17 & $1.2 \times 10^{-7}$ & $\mathrm{FP} ;{ }^{137} \mathrm{Ba}(n, p)$ \\
\hline${ }^{146} \mathrm{Sm}$ & $1.03 \times 10^{8}$ & - & $\mathrm{FP} ;{ }^{147} \mathrm{Sm}(n, 2 n)$ \\
\hline${ }^{151} \mathrm{Sm}$ & 90 & $1.4 \times 10^{-5}$ & $\mathrm{FP} ;{ }^{150} \mathrm{Sm}(\mathrm{n}, \gamma)$ \\
\hline $150_{\mathrm{Eu}}$ & 36 & - & ${ }^{151} \mathrm{Eu}(n, 2 n)$ \\
\hline${ }^{152} \mathrm{Eu}$ & 13.48 & $8.4 \times 10^{-7}$ & ${ }^{151} \mathrm{Eu}(n, \gamma) ;{ }^{153} \mathrm{Eu}(n, 2 n)$ \\
\hline${ }^{154} \mathrm{Eu}^{* *}$ & 8.59 & $6.7 \times 10^{-7}$ & ${ }^{153_{\mathrm{Eu}}(n, \gamma)}$ \\
\hline $166 \mathrm{~m}_{\mathrm{Ho}}$ & $1.2 \times 10^{3}$ & - & $\mathrm{FP} ;{ }^{165} \mathrm{Ho}(\mathrm{n}, \gamma)$ \\
\hline $178 \mathrm{~m}_{\mathrm{Hf}}$ & 31. & - & ${ }^{177_{\mathrm{Hf}}(\mathrm{n}, \gamma)}$ \\
\hline $186 \mathrm{~m}_{\mathrm{Re}}$ & $2.0 \times 10^{5}$ & - & ${ }^{185} \operatorname{Re}(n, \gamma) ; 186$ Os $(n, p)$ \\
\hline $192 m_{I r}$ & $24 . \times 10^{1}$ & - & ${ }^{191} \operatorname{Ir}(n, \gamma) ; 193 \operatorname{Ir}(n, 2 n)$ \\
\hline
\end{tabular}




\begin{tabular}{|c|c|c|c|}
\hline${ }^{193} \mathrm{Pt}$ & 60 & $4.6 \times 10^{-5}$ & ${ }^{192} \mathrm{Pt}(n, \gamma) ;{ }^{194} \mathrm{Pt}(n, 2 n)$ \\
\hline${ }^{205} \mathrm{~Pb}$ & $1.5 \times 10^{7}$ & - & ${ }^{204} \mathrm{~Pb}(\mathrm{n}, \gamma) ;{ }^{206} \mathrm{~Pb}(\mathrm{n}, 2 \mathrm{n})$ \\
\hline $210 \mathrm{~Pb}$ & 22.3 & $1.0 \times 10^{-9}$ & natural $(\mathrm{RaA})$ \\
\hline${ }^{231} \mathrm{~Pa}$ & $3.28 \times 10^{4}$ & $1.0 \times 10^{-8}$ & $\begin{array}{l}\text { natural; decay of device }{ }^{235} \mathrm{U} ;{ }^{232} \mathrm{Th} \\
(\mathrm{n}, 2 \mathrm{n})\end{array}$ \\
\hline${ }^{232} \mathrm{Th}$ & $1.40 \times 10^{10}$ & $9.2 \times 10^{-8}$ & natural and device component \\
\hline $232 \mathrm{U}$ & 70. & $1.0 \times 10^{-8}$ & device component; ${ }^{233} \mathrm{U}(\mathrm{n}, 2 \mathrm{n})$ \\
\hline${ }^{233} \mathrm{U}$ & $1.592 \times 10^{5}$ & $2.6 \times 10^{-8}$ & device component; radiochemical tracer \\
\hline${ }^{234} \mathrm{U}$ & $2.46 \times 10^{5}$ & $2.6 \times 10^{-8}$ & natural and device component \\
\hline${ }^{235} \mathrm{U}$ & $7.04 \times 10^{8}$ & $2.6 \times 10^{-8}$ & natural and device component \\
\hline${ }^{236} \mathrm{U}$ & $2.342 \times 10^{7}$ & $2.7 \times 10^{-8}$ & device comp.; ${ }^{235} U(n, \gamma) ;{ }^{238} U(n, 2 n)^{2}$ \\
\hline $238 \mathrm{U}$ & $4.47 \times 10^{9}$ & $2.6 \times 10^{-8}$ & natural and device component \\
\hline${ }^{237} \mathrm{~Np}$ & $2.14 \times 10^{6}$ & $7.2 \times 10^{-9}$ & $\begin{array}{l}\text { device component; radiochemical tracer; } \\
\text { decay of }{ }^{237} \mathrm{U}\end{array}$ \\
\hline $238 \mathrm{Pu}$ & 87.7 & $7.2 \times 10^{-9}$ & $\begin{array}{l}\text { device component; radiochemical tracer; } \\
{ }^{239} \mathrm{Pu}(n, 2 \mathrm{n})\end{array}$ \\
\hline${ }^{239} \mathrm{Pu}$ & $2.410 \times 10^{4}$ & $6.5 \times 10^{-8}$ & device component.; decay of ${ }^{239} \mathrm{U}$ \\
\hline $240 \mathrm{Pu}$ & $6.56 \times 10^{3}$ & $6.5 \times 10^{-8}$ & device component \\
\hline $241_{P u}$ & 14.4 & - & device component \\
\hline${ }^{242} \mathrm{Pu}$ & $3.75 \times 10^{5}$ & $6.8 \times 10^{-8}$ & device component; radiochemical tracer \\
\hline${ }^{241} \mathrm{Am}$ & 432.7 & $6.4 \times 10^{-9}$ & $\begin{array}{l}\text { device component; radiochemical tracer; } \\
\text { decay of }{ }^{241} \mathrm{Pu}\end{array}$ \\
\hline${ }^{243} \mathrm{Am}$ & $7.37 \times 10^{3}$ & $6.5 \times 10^{-9}$ & device component; radiochemical tracer \\
\hline${ }^{244} \mathrm{Cm}$ & 18.1 & $1.0 \times 10^{-8}$ & radiochemical tracer \\
\hline
\end{tabular}

* MPC $=$ Maximum Permissible Concentration from U.S. Environmental Protection Agency, Federal Register, v. 56, no. 138, July 18, 1991, p. 33050-33127.

** Short-lived radionuclides not included in the Goishi et al. (1994) inventory but important for transport and near-field modeling.

\section{LIMITATIONS OF SAMPLING CONTAMINATED GROUNDWATERS}

Few samples and analyses exist for impacted groundwaters owing to the technical challenge and cost of obtaining data near test centers. Occurrences of impacted water at the Nevada Test Site have been reported by Borg et al. (1976), Nimz and Thompson (1992), Thompson (1995a) and Esser (in preparation). Radionuclides have been detected in NTS groundwater produced from a number of wells including UE-4g\#2, an exploratory hole drilled east of hole U-4g; U-3kz, an emplacement hole for the ALEMAN event; UE-2ce, a satellite well to the NASH event; RNM\#2S a satellite well 
drilled for hydrologic investigations of the CAMBRIC event; U-2aw an emplacement hole neighboring the COMMODORE event; UE-2ar, an exploratory hole south of the AGILE event; UE-7ns, a satellite well associated with the BOURBON event; UE-20n\#1, a dedicated hydrologic satellite hole drilled downgradient from the CHESHIRE event; $U-19 \mathrm{v}$, a re-entry post-shot hole associated with the ALMENDRO event; PM-2, a well predating the neighboring SCHOONER cratering event; U2gg PSE-3A, a satellite well drilled to the water table beneath the INGOT event and UTba PS-1as, a well completed into the cavity of the BASEBALL event. At U-2aw and UE-7ns, tritium was the only detectable radionuclide; the other sites yielded waters with detectable quantities of tritium, fission products and/or activation products.

The impacted groundwaters described above were collected from a variety of sources including dedicated satellite wells, exploratory wells and re-entry (post-shot) wells. The well completions were constructed for different purposes (geologic sampling, device emplacements, post-shot debris sampling) using drilling technologies appropriate at the time but not necessarily optimized for the collection of representative cavity or near-cavity water samples. In particular, drilling additives and lubricants often included prodigious quantities ( $>\sim 1.19 \times 10^{6} \mathrm{~L}$ per hole) of montmorillonite, sepiolite, $\mathrm{NaOH}$ and $\mathrm{KCl}$ in addition to organics and organic polymers (Bryant and Fabryka-Martin, 1991) which, in the case of post-shot sampling, are forced into the hole with no return circulation. The clay species have high sorptive capacity for radionuclides; basic solutions will increase the $\mathrm{pH}$ of the water and promote dissolution of silicate phase and the release of radionuclides. In addition, many completions at the NTS were constructed with carbon steel which has severely corroded within a decade after construction (DOE, 1994). Secondary oxides also have a high sorptive capacity for radionuclides and will bias representative sampling.

The type and frequency of sample collection dramatically affects measured radionuclide concentrations. As noted by Thompson (1995a), a number of contaminated wells that had been continuously pumped (i.e. CAMBRIC, NASH, CHESHIRE) in support of groundwater monitoring are now occasionally sampled by bailer. While removal of pumps reduces maintenance costs and the potential for the surface discharge of radioactivity, Thompson (1995a) demonstrated the inconsistency of radiochemical data returned from single grab samples relative to continuously pumped samples. Without adequate purging and development of the well, water chemistry never stabilizes due to inadequate mixing within the well bore. Recent experience at CAMBRIC RNM-2S indicates that from a static condition several hours of pumping time (in excess of $2 \mathrm{~m}^{3} /$ hour) is necessary to develop the well before concentrations of conservative species (tritium) stabilize in the effluent water (Thompson, 1995a). Additionally, results from a field test at the DOE Hanford Reservation indicates that a well development 
ratio greater than 100 (volume of fluid removed divided by the volume of fluid lost during drilling) is required for a 1000-fold reduction in conservative (tritium), non-conservative (fluorescine) and indicator (total organic carbon) drilling fluid tracer constituents; a ratio of greater than 1000 may be required for certain isotopes $\left({ }^{129} \mathrm{I},{ }^{36} \mathrm{Cl},{ }^{14} \mathrm{C}\right.$ and others) (Graham and Johnson, 1991).

One of the limitations of sampling contaminated waters to estimate the hydrologic source term is that measured activities will be site and time specific. Water data must be combined with information on the boundary conditions responsible for controlling geochemistry. Without knowing what controls the dissolved-phase concentration of a specific radionuclide in a specific cavity at a specific time, the data cannot be extrapolated from the measured concentration to different cavity waters or the same cavity waters 100 years in the future.

Because of the problems associated with sampling in situ waters representative of the hydrologic source term, an empirical estimate of the hydrologic source term is difficult. Alternately, the hydrologic source term may be calculated by converting the radiologic source term to its hydrologic equivalent. This approach involves applying attenuation factors derived from laboratory and field studies to a specific radiologic inventory to estimate its hydrologic equivalent. The latter is complicated by incomplete knowledge of those factors which determine attenuation including initial distribution, sorption, solubility, matrix verses advective (fracture) transport and mobility as colloidal species. Other relevant factors such as radioactive decay are well known.

\section{ATTENUATION FACTORS}

Radionuclides deposited in the subsurface following a nuclear test are not equally available for groundwater transport. Several factors complicate the release function. The initial spatial and chemical distribution of radionuclides is heterogeneous. Some radionuclides are predominantly associated with the melt matrix and are only accessible to groundwater through slow processes such as glass dissolution. Other radionuclides are predominantly associated with surfaces and are accessible to groundwaters through fast processes such as ion exchange. Because melt debris is extremely heterogeneous in distribution and character, modeling the initial release of matrix-incorporated radioactivity is difficult. Similarly, because cavity debris is a heterogeneous mixture of particles of different sizes and compositions with poorly known surface properties, modeling the distribution and release of radioactivity condensed onto solid surfaces is also difficult. A description of the release and distribution of radionuclides associated with an underground nuclear explosion is outside the scope of this report; interested readers are referred to Goishi et al. (1994) and Smith (1994). 
Once in solution, a number of processes may control the concentration and transport of dissolved phase radionuclides in the near-field environment. These processes include solubility with respect to secondary phases, surface processes and/or colloidal processes. Note that solubility is a thermodynamic property and hence applies to all radionuclides and stable isotopes of a given element. Solubility is driven by $\mathrm{pH}$, Eh and temperature of cavity waters (all of which are variable from event to event, and over time for a single event). For the same reasons which make modeling the initial release of surfacedeposited radionuclides problematic, modeling near field sorption of dissolved phase radionuclides (regardless of whether they were initially surface or volume deposited) is also problematic. Finally, colloid formation provides a mechanism for the migration of radionuclides which are otherwise insoluble or strongly sorbed to surfaces.

Borg et al. (1976) and Smith (1993) provide a review of controls affecting the transition between the radiological and hydrologic source terms. Important to this discussion is the time elapsed from zero time. The radionuclide source term is not static but will be affected by the radioactive decay of tritium, fission products and activation products (Borg et al., 1976). The decay of tritium is rapid and will decrease approximately one order of magnitude in 41 years and 5 orders of magnitude in 200 years. The decay of activation products produced in underground nuclear tests is even faster. At zero time plus 0.5 years, the activity per kiloton due to fission products is 30 times that due to activation products; the ratio increases to 88 at twenty five years and 229 at 100 years. Hence elapsed time is important in elucidating the relative contributions of tritium, fission products and activation products to the source term.

Mobilization of radionuclides from test debris may involve leaching, sorption and colloid formation. These are discussed in the following sections.

\section{LEACHING}

Glass stability studies have historically complemented a part of a groundwater protection strategy supporting the nuclear test program. Additional studies have been sponsored in large part by the Yucca Mountain Project (YMP) which proposes to dilute spent high level radioactive defense waste in a borosilicate glass matrix before permanent disposal in a high level waste repository at Yucca Mountain. The two matrices, nuclear waste and nuclear explosive melt debris, are compositionally and texturally distinct and should not be directly compared. As summarized by Borg (1976) and Smith (1993), the leaching of nuclear explosive melt debris is affected by composition, initial distribution of radionuclides, available surface area of the melt debris, chemistry of the leaching solution and the temperature of waters inside the cavity. Glass (1984) has demonstrated the solubility dependence of natural glasses on their composition; dissolution of natural glasses in terrestrial 
environments increases with increasing $\mathrm{Fe}$ and $\mathrm{Mg}$ concentrations and decreases with increasing $\mathrm{Si}, \mathrm{Al}, \mathrm{Ca}, \mathrm{Na}$ and $\mathrm{K}$ contents. Higgins (1959) speculated that working point debris enriched in $\mathrm{Si}$ and $\mathrm{Al}$ might be more insoluble than debris enriched in $\mathrm{Ca}$ and $\mathrm{K}$.

Radionuclides which are surface rather than volume incorporated are more susceptible to leaching. Zones of prompt injection are particularly susceptible where short lived gaseous fission products, particulariy ${ }^{137} \mathrm{Xe}$ and $90 \mathrm{Kr}$, are injected and condense shortly after detonation. Leaching rates increase with decreasing particle size and increasing available surface area. The zone of fracturing surrounding the working point coupled with the cavity collapse create an extremely poorly sorted matrix with variable porosity. Air permeabilities measured for undisturbed NTS tuff ranges from 0.04 to 0.10 darcies (Morris, 1971); by contrast, permeabilities for three event chimneys, assuming a porosity of 33\%, range between 12 and 63 darcies (Rozsa et al., 1974). Large spalled blocks fall into the vitreous melt puddle at the bottom of the cavity; the surrounding lithology is shock pulverized to a maximum distance between three and five cavity radii from the working point (Smith, 1994). The extreme temperatures (to $10^{6} \mathrm{~K}$ ) and pressures (to Mbar) associated with the explosion obliterate any regular stratigraphy. Particle size and available surface areas depend on the energy release by the explosion and the competence of the host media to the extreme temperatures and pressures associated with the explosion. Finally, the chemistry of the water infiltrating the cavity will greatly affect the solubility of the constituent radionuclides. Waters with higher $\mathrm{pH}$ will preferentially dissolve silicate phases; waters with higher Eh will promote the transport of soluble higher oxidation state species including $\mathrm{U}, \mathrm{Pu}$ and $\mathrm{Np}$. Cavity waters from particular events including ALMENDRO, FAULTLESS and CHESHIIRE display high cavity temperatures $\left(30\right.$ to $50^{\circ} \mathrm{C}$ ) twenty years after detonation (Chapman et al., 1994, Erikson, 1991, Thompson, 1995a). Higher cavity temperatures will promote reaction kinetics and facilitate dissolution; experimental studies of borosilicate glass dissolution emphasize the effect of $\mathrm{pH}$, time and temperature on glass stability (Knauss et al., 1990).

The 1981 BASEBALL (UTba) event cavity was drilled in 1994. Results from over seventy samples collected from side-wall core from one re-entry and one sidetrack hole confirm that the expected fractionation of volatile from refractory fission and activation products is preserved over the thirteen year interval since detonation (Thompson, 1995b). Lower boiling point species are dispersed throughout the cavity while refractory species are incorporated exclusively in the lower puddle region containing melt-glass. Tritium was analyzed from waters returned with the solids; tritium profiles are similarly preserved. As emphasized by Thompson (1995b), the results from BASEBALL indicate that in regions of low groundwater flow, there may be only insignificant release and migration of radioactive material over ten years post event. While these results have significant implication for radionuclide 
migration associated with single events on Yucca Flat, the controls have yet to be identified and cannot be extrapolated to a general case for the NTS.

\section{SORPTION AND MATRIX EFFECTS}

Interaction of radionuclides borne by groundwaters with the surrounding geologic media will significantly retard transport and dispersal. Much of the geology of the Nevada Test Site is composed of Miocene and younger ashflow and ash fall tuffs with interbedded rhyolites (Sawyer et al., 1994) which contain highly sorptive minerals. Similarly, overlying basal Quaternary alluvial sequences are largely $(\sim>95 \%$ by rock mode) comprised of clastics derived from these volcanic sources (Wagoner, 1987). Sorption comprises a variety of physiochemical processes including ion exchange, adsorption and chemisorption and requires knowledge of the distribution of sorbing minerals neighboring each event cavity. Sorption is defined relative to the distribution coefficient, $\mathrm{K}_{\mathrm{d}}$, which is defined as:

$$
K_{d}=\frac{\text { (amount of } X \text { within solid) } / \text { (weight of solid })}{\text { (amount of } X \text { within solution) } /(\text { volume of solution })}
$$

Theoretically, the total retardation will be the sum of individual sorption coefficients multiplied by the abundance of the each sorbing phase:

$$
\sum^{n} K_{d}=K_{\mathrm{d} 1}(\text { abundance } 1)+K_{\mathrm{d} 2}(\text { abundance } 2)+\ldots . . .+K_{\mathrm{dn}}(\text { abundance } \mathrm{n})
$$

A number of parameters combine to compromise theoretical behavior. Groundwater composition, the oxidation state and specific radionuclide in solution, fluid temperature and the abundance, composition and cation exchange capacity of minerals comprising the host lithology determine a singular $\mathrm{K}_{\mathrm{d}}$ for each underground event site (Ogard, 1984). In particular sorption is moderated by the ionic size, electronegativity, oxidation state and solubility of a particular radionuclide. The formation of aqueous complexes, particularly large anions, attenuates sorptive capacity; alternately if the oxidation state favors strongly ionic species, ion exchange reactions are enhanced. Decreasing particle size will increase $\mathrm{K}_{\mathrm{d}}$. Changes in fluid $\mathrm{pH}$ and concentration affect sorption; for dilute waters $\left(\mathrm{Na}^{+}, \mathrm{K}^{+}, \mathrm{Ca}^{+2}\right.$ and $\mathrm{Mg}^{+2}$ at concentrations of $0.002 \mathrm{~N}$ ), with few competing cations, radionuclides are effectively removed from solution and $\mathrm{K}_{\mathrm{d}} \mathrm{s}$ are very large. In more concentrated solutions $(0.2 \mathrm{~N})$, assuming ion exchange dominates, a higher abundance of competing cations will lower sorption ratios. Finally, mineralogy provides a primary control. Clays and zeolites, which together may comprise more than $80 \%$ modal mineralogy of some altered tuffs at the Nevada Test Site, display strong ion exchange behavior which dominates sorption in these rocks (Bish and Chipera, 1989). Groundwater flow combines 
matrix flow and advective flow. Thus, the presence of sorbing fracture lining minerals must also be considered. It should be emphasized that specific geochemical and mineralogic controls on sorption are also time specific. Forward extrapolation of sorptive capacity in the presence of an evolving hydrologic source term is particularly problematic. Transfer of time or site specific sorption data to the Nevada Test Site as a whole without systematic characterization of the solid and liquid phases at a limited number of contaminated sites is misleading.

Three dimensional depth profiling studies by ion microprobe of NTS tuff exposed to a $235 \mathrm{U}, 238 \mathrm{U}$ and ${ }^{239} \mathrm{Pu}$ doped solutions of dilute bicarbonate NTS groundwater indicate radionuclide transport is a composite of a "slow path" (matrix diffusion) and a "fast path" (fracture) flow (McKeegan et al., 1989, Buchholtz-ten. Brink et al., 1991). Apparent diffusion coefficients were calculated from profiles of tracer abundance verses depth. A matrix diffusion coefficient of $1 \times 10^{-12} \mathrm{~cm}^{2} / \mathrm{sec}$ assumes $95 \%$ of pore volume is within pores between 0.01 and $0.1 \mathrm{~mm}$ equivalent diameter and the remaining $5 \%$ is within pores or microfractures between 10 and $100 \mathrm{~mm}$ equivalent diameter. In saturated advective systems most of the transport occurs in microfractures along intergranular boundaries (McKeegan et al., 1989). The geochemical heterogeneity of the solid and fluid phase also provide additional controls on the calculated diffusion coefficient.

\section{COLLOIDS}

Studies at the CHESHIRE (U20n) event by Buddemeier and Hunt (1988) suggest that colloids in the range of 100,000 to $10,000 \mathrm{MWU}(0.006$ to $0.003 \mu \mathrm{m}$ respectively) sorb radioactive $\mathrm{Mn}, \mathrm{Co}, \mathrm{Cs}, \mathrm{Ce}$ and Eu species. Colloids are enriched in the CHESHIRE cavity relative to formation waters. $X$-ray diffraction studies indicate the colloids are composed of $\mathrm{Ca}-\mathrm{K}$ feldspars and fine clays. Buddemeier and Hunt (1988) suggest that while both dissolved and colloidal radionuclides are transported by fracture flow, colloidally sorbed radionuclides are transported less efficiently than soluble neutral or anionic species. Because high colloid concentrations may be characteristic of cavity in addition to CHESHIIRE, colloids may potentially facilitate radionuclide migration throughout larger areas of the Nevada Test Site. Buddemeier and Hunt (1988) note that drilling and development activities may affect colloid generation, resuspension and transport. Similarly production of water from the sampling well may stress the aquifer and introduce abnormally high particulate loadings. Movement of contaminants by colloids may be enhanced in partially clogged fractures (Kessler and Hunt, 1994). Finally artifacts of sampling or characterization which affect particle size may bias quantitative predictions of transport. Given these uncertainties, the role of colloids in radionuclide transport at NTS needs to be investigated. 


\section{TRITIUM}

The foregoing sections detail factors inhibiting the availability of the radiologic source term for transport by groundwater. In contrast tritium is unaffected by these factors. The equivalence of the radiologic and hydrologic source term for tritium is discussed in the following section.

Tritium has a half life of 12.43 years. It is produced naturally in the atmosphere by energetic reactions of cosmic rays with nitrogen by the following reaction:

$$
14_{\mathrm{N}}+{ }^{1} \mathrm{n}=12 \mathrm{C}+3_{\mathrm{H}}
$$

It is also associated with nuclear weapons where it is both loaded on the device and produced in abundance by thermonuclear fuel burn. As an isotope of hydrogen, tritium can readily incorporate itself in the water molecule as HTO. Typically, $99.9 \%$ of the tritium occurs as molecular HTO. The natural production of tritium in rainwater is approximately $32 \mathrm{pCi} / \mathrm{L}$. The State of Nevada drinking water standard is $2.0 \times 10^{4} \mathrm{pCi} / \mathrm{L}$. The MCL proposed by the U.S. EPA for tritium is $6.09 \times 10^{4} \mathrm{pCi} / \mathrm{L}$. Enrichments in tritium values in NTS groundwaters above the precipitation threshold are highly diagnostic of waters impacted by subsurface nuclear weapons testing. Measurements of non-impacted groundwaters collected from NTS monitoring and water supply wells in 1992 and 1993 range between 0.3 and 60 $\mathrm{pCi} / \mathrm{L}$. By contrast, field tritium scans for groundwaters collected from "hot" wells near sites of subsurface detonations range from $5 \times 10^{2}$ to $8 \times 10^{7} \mathrm{pCi} / \mathrm{L}$ (Davisson et al., 1994, Thompson, 1995a).

For 100-200 years post-test, residual tritium in or near the saturated zone has the highest activity of any radionuclide with $t_{1 / 2}>10$ years (Goishi et al., 1994). The amount of tritium incorporated in the radionuclide source term is the sum of the tritium loaded on a device initially, the tritium produced during burning of the thermonuclear fuel and the tritium destroyed in the explosion. The largest contribution is from the burning of thermonuclear fuel. During a nuclear explosion temperatures may exceed $1 \times 10^{6} \mathrm{~K}$ within the weapons case. Pressures may exceed $1 \mathrm{Mbar}$. At firing (zero) time, most of the tritium associated with a thermonuclear explosion likely exists as a free radical $\left({ }^{3} \mathrm{H}^{+}\right)$. Water originally sited in rock near the working point is vaporized by the extreme temperature associated with the explosion. This water includes water liberated during both melting and vaporization of rock and includes structural water bound in minerals (conventionally reported as $\mathrm{H}_{2} \mathrm{O}^{+}$). Due to the temperature and pressures associated with detonation, the tritium produced by the explosion mixes with the vaporized water at temperatures high enough to allow dissociation of the water molecule and subsequent incorporation of the tritium in the structure. The molecular 
tritium remains as a vapor in the rubblized explosion chimney before cooling and condensing as water when temperatures fall below the boiling point.

The abundance of post-test tritium in groundwater relative to other radionuclides should be emphasized. The CAMBRIC event (U5e) was a 0.75 Kt underground nuclear test fired in May, 1965 73m below the static water level in alluvium of Frenchman Flat. Results of re-entry drilling and sampling of both solids and water collected from the returns constituted a field study of radionuclide migration associated with the effects of underground nuclear testing. Hoffman (1979) defines an effective retention factor, $\mathrm{E}_{d}$, as:

$$
\mathrm{E}_{\mathrm{d}} \approx \frac{\mathrm{A}_{x}(\text { solid })}{\left.\mathrm{A}_{\mathrm{x}} \text { (solution }\right)}
$$

where $A_{X}$ (solid) is the activity of radionuclide $X$ in the solid phase corrected to zero (firing) time and $A_{x}$ (solution) is the activity of the same radionuclide in the liquid phase corrected to zero time assuming the fraction of the radionuclide not in solution is incorporated in the solid phase. The effective retention factors for CAMBRIC range from $>10^{7}$ for ${ }^{239} \mathrm{Pu}$ to $>10^{6}$ for ${ }^{147} \mathrm{Pm}$ to $10^{4}$ for ${ }^{137} \mathrm{Cs}, 10^{3}$ for ${ }^{90} \mathrm{Sr}$ and $10^{2}$ for ${ }^{90} \mathrm{Sr}$ and ${ }^{106} \mathrm{Ru}$. By contrast, the retention factor for tritium is zero.

Because nearly all of the tritium is incorporated in the water molecule as HTO, tritium is an excellent measure of both the radiologic and hydrologic source terms. Tritium is conservative under saturated conditions and will not be depleted nor enriched in groundwater by chemical processes including ion-exchange, speciation, dissolution or precipitation. Accordingly, tritium represents a source term species whose abundance has been calculated with accuracy (within a factor of 3 ) and, because tritium is conservative, there is little ambiguity relating the radiologic to the hydrologic source term. For events fired below the water table, tritium activities define the hydrologic source term for 100 to 200 years post-test. A tritium-only hydrologic source term is presently both representative and technically defensible. Finally, because tritium is conservative, the abundance of other dissolved radionuclides may be normalized against the tritium concentration to identify a total hydrologic source term.

\section{SUMMARY and DISCUSSION}

As discussed above the definition of a representative hydrologic source term for modeling purposes is complicated by a number of factors. Chief among these are: 
- Direct measurement of impacted cavity waters are biased by drilling and completion techniques that contaminate water produced from these wells.

- The NTS radiologic source term inventory (Goishi et al., 1994) omits radionuclides with half-lives less than ten years but which are produced in great abundance in a nuclear event. Omission of short-lived fission and activation products precludes conversion of the radiologic to the hydrologic source term for radionuclides with significant activities for $\leq 100$ years post-test.

- The transfer of radionuclides from the radiologic to the hydrologic source term is a two stage process involving both leaching from solid debris and sorption onto surrounding rubble or neighboring fractured rock. The relative importance of leaching or sorption in defining the hydrologic source term is presently unknown.

- While studies of the stability of glasses have steadily constituted a part of a groundwater protection strategy supporting the nuclear test program, only preliminary statements can be made regarding melt debris performance under saturated or partially saturated conditions. Leaching of melt debris is affected by it composition, it initial distribution of radionuclides, the available surface area of the melt debris, the chemistry of the.leachate and the temperature inside the cavity. Little comprehensive information exists on these topics.

- Sorption comprises a variety of physiochemical processes including ion exchange, adsorption and chemisorption and requires knowledge of both groundwater flowpaths and the distribution of sorbing minerals proximal to the radiologic source term. Sorption coefficients are moderated by groundwater composition, the oxidation state and specific radionuclide in solution, the fluid temperature and the abundance, composition and cation exchange capacity of minerals comprising the host lithology. The only representative data for sorption at the Nevada Test Site has been assembled in support of the Yucca Mountain Project (Triay at al., 1991; Thomas, 1987). Information on geochemical controls is presently lacking.

- Radionuclide transport is a composite of a "slow path" (matrix diffusion) flow and a "fast path" (fracture) flow. Apparent diffusion coefficients calculated to-date are not representative of all NTS lithologies incorporating testing centers; much more supporting information, particularly on fracture systematics near event cavities, is required.

- There is evidence that colloids potentially sorb insoluble radionuclides and facilitate their movement through saturated fractured rock. Colloid loadings are affected by well construction, development and production. The extent of colloidal loadings in NTS groundwaters is unknown. 
- For 100-200 years post-test, residual tritium in or near the saturated zone has the highest activity of any radionuclide with $t_{1 / 2}>10$ years.

- Because $99.9 \%$ of the tritium is incorporated in the water molecule as HTO, tritium is an excellent measure of both the radiologic and hydrologic source terms. Tritium is conservative under saturated conditions and will not be depleted nor enriched in groundwater by chemical processes including ion-exchange, speciation, dissolution or precipitation.

For these reasons, definition of the hydrologic source term for fission and activation products that have high activities for decades following underground testing involves knowledge and assumptions which are presently unavailable. At this time, a hydrologic source term that attempts to include these components in the absence of further data is not technically defensible. To advance beyond the initial source term estimates for the first phase of modeling requires generating new data to adequately constrain the transport model. In contrast, for tritium, the radiologic source term is known with accuracy and, near or within the saturated zone, is equivalent to the hydrologic source term.

\section{RECOMMENDATIONS}

Because of the many unresolved difficulties in either measuring the hydrologic source term or converting the radiologic source term to a hydrologic source term, selection of the source term values for the initial phase of modeling must be made cautiously. There is a danger in using technically indefensible estimates when further study will almost certainly show them to be invalid. Worse, use of the unconvincing data may disqualify the modeling results. It is proposed here that a more limited, but technically defensible, source term be used with appropriate caveats about the need to include additional source term data when they can be adequately supported. This recommendation is explained in the following paragraphs:

- Transport modeling should proceed using a tritium-only source term which can be averaged to an unclassified per-event inventory. Tritium has the highest activity of any radionuclide species for 100 to 200 years post-test. The tritium inventory for the Nevada Test Site is known to a within a factor of three. Because $99.9 \%$ of the ${ }^{3} \mathrm{H}$ occurs as HTO, a conservative molecule, the hydrologic source term for tritium can be quantified.

- Subsequent phases of transport modeling will require systematic investigation of the behavior of fission products, activation products and actinides under saturated or partially saturated conditions to define a representative hydrologic source term. 
- Future scope of work should recognize the importance of the hydrologic source term to the stated goal of the project: risk to potential receptors. Source term refinement must complement on-going hydrologic characterization. It must be remembered that, for project objectives, these two elements are interdependent. Future work must emphasize systematics including how contaminant species are mobilized and their potential for retardation. As these data are returned, a significant number of potential contaminants may be eliminated from the risk assessment. UGTA Operable Unit field and laboratory studies must provide data on the initial distribution of radionuclides, their availability under saturated or partially saturated conditions, likely transport pathways and their potential for retardation in solution or as colloids.

Given the emphasis of data gathering in support of the flow model, a priority of the RI/FS should be to promote source term studies where knowledge is incomplete and assumptions remain untested. The experience of the Yucca Mountain Project should not be lost during this exercise. Since the early 1980's YMP near-field studies have included systematic characterization of an engineered barrier system including specific waste packages and waste forms (Short et al., 1991, Chesnut, 1992). By contrast, the heterogeneous "waste forms" produced by underground nuclear testing remain largely uncharacterized. Existing knowledge of the nuclear test waste form is derived from sporadic historical data collected for different purposes from unrelated sources. The RI/FS will be founded on data quality objectives (DQOs) necessary to qualify a technically credible plan of remedial action; adequate characterization in the near-field will identify DQOs relevant to this process.

\section{ACKNOWLEDGMENTS}

This report originated from discussions at a February, 1995 meeting hosted by the U.S. Department of Energy, Nevada Operations Office, Environmental Restoration Division to assess the hydrologic source term for the Nevada Test Site. Roger Jacobson of the Desert Research Institute and Janet Wille of the IT Corporation contributed many of the ideas later incorporated in this document. Doug Duncan of the DOE/NV's Environmental Restoration Division both offered technical advice as well as provided critical review of an earlier version of the manuscript.

This work sponsored by the Underground Test Area Operable Unit of the U.S. Department of Energy, Nevada Operations Office, Environmental Restoration Division. 


\section{BIBLIOGRAPHY}

Bish, D.L. and S.J. Chipera, 1989, Revised Mineralogic Summary of Yucca Mountain, Nevada, Los Alamos National Laboratory, LA-11497-MS.

Borg, I.Y., R. Stone, H.B. Levy and L.D. Ramspott, 1976, Information Pertinent to the Migration of Radionuclides in Ground.Water at the Nevada Test Site, Part 1: Review and Analysis of Existing Information, Lawrence Livermore National Laboratory, UCRL-52078, Part 1.

Bryant, E.A. and J. Fabryka-Martin, 1991, Survey of Hazardous Materials Used in Nuclear Testing, Los Alamos National Laboratory, LA-12014-MS.

Buchholtz-ten Brink, M., D.L. Phinney and D.K. Smith, 1991, Effects of Heterogeneity on Actinide Diffusion Rates in Tuffaceous Rocks, High Level Radioactive Waste Management, Proceedings of the Second International Conference, America Society of Civil Engineers and American Nuclear Society, p. 161-168.

Buddemeier, R.W and J.R. Hunt, 1988, Transport of Colloidal Contaminants in Groundwater: Radionuclide Migration at the Nevada Test Site, Applied Geochemistry, v.3, p. 535-548.

Chapman, J.B., T.M. Mihevc and B.F. Lyles, 1994, The Application of Borehole Logging to Characterize the Hydrogeology of the Faultless Site, Central Nevada Test Area, Desert Research Institute, DOE/NV/10845-35, UC-703.

Chesnut, D.A., 1992, Characterizing the Altered Zone at Yucca Mountain: The Beginning of a Testing Strategy, Lawrence Livermore National Laboratory, UCRL-JC-109231 Preprint.

Davisson, M.L., J.M. Kenneally, D.K. Smith, G.B. Hudson, G.J. Nimz and J.H. Rego, 1994, Preliminary Report on the Isotope Hydrology Investigations at the Nevada Test Site: Hydrologic Resources Management Program, Lawrence Livermore National Laboratory, UCRL-ID-116122.

DOE, see U.S. Department of Energy.

Erikson, S.J., 1991, Report of Drilling and Radionuclide Migration Investigations at UE20n\#1, Pahute Mesa, Nevada Test Site, 1987, Desert Research Institute, DOE/NV/10384-35, UC-703.

GeoTrans, Inc., 1994, A Comprehensive Chemistry Database for Groundwater and Springs at the Nevada Test Site and Vicinity. 
Glass, B.P., 1984, Solution of Naturally Occurring Glasses in the Geological Environment in Natural Glasses (L.D. Pye, J.A. O'Keefe and V.D. Frechette, eds.) North-Holland, Amsterdam.

Goishi, W., B. Esser, J. Meadows, N. Namboodiri, D. Smith, J. Wild, S. Bowen, P. Baca, L. Olivas, C. Geoffrion, J. Thompson and C. Miller, 1994, Total Radionuclide Inventory Associated with Underground Nuclear Tests Conducted at the Nevada Test Site 1955-1992 (U), Los Alamos National Laboratory, LA-CP-94-0222, SECRET-RESTRICTED DATA.

Graham, D.L. and V.G. Johnson, 1991, Effects of Fluid Rotary Drilling on Hydrochemical Sampling Results from Deep Boreholes in Fractured Columbia River Basalt, Journal of Hydrology, v. 128, p. 171-212.

Higgins, G.H., 1959, Evaluation of the Ground Water Contamination Hazard from Underground Nuclear Explosions, Journal of Geophysical Research, v. 64, p. 1509-1519.

Hoffman, D.C., 1979, A Field Study of Radionuclide Migration, in S. Fried (ed) Radioactive Waste in Geologic Storage, American Chemical Society Symposium Series, no. 100, p. 149-166.

Kessler, J.H. and J.R. Hunt, 1994, Dissolved and colloidal contaminant transport in a partially clogged fracture, Water Resources Research, v. 30, p. 11995-11206.

Knauss, K.G, W.L. Bourcier, K.D. McKeegan, C.I. Merzbacher, S.N. Nguyen, F.J. Ryerson, D.K. Smith, H.C. Weed and L. Newton, 1990, Dissolution Kinetics of a Simple Analogue Nuclear Waste Glass as a Function of $\mathrm{pH}$, Time and Temperature, Materials Research Society, Symposium Proceedings, Scientific Basis for Nuclear Waste Management XIII, v. 176. p. 371-381.

McKeegan, K.D., D. Phinney, V.M. Oversby, M. Buchholtz-ten Brink and D.K. Smith, 1989, Uranium Transport in Topopah Spring Tuff: An Ion-Microscope Investigation, Materials Research Society, Symposium Proceedings, Scientific Basis for Nuclear Waste Management XII, v. 127. p. 813-821.

Morris, G.A., 1971, Preliminary Estimates of Permeability of Media Around Hole UE2a-1, Lawrence Radiation Laboratory - Livermore, Chemistry Department Technical Note no. 71-51.

Nimz, G.J. and J.L. Thompson, 1992, Underground Radionuclide Migration at the Nevada Test Site, U.S. Department of Energy, Nevada Field Office, DOE/NV-346, UC-703. 
Ogard, A.E., K. Wolfsberg, W.R. Daniels, J. Kerrisk, R.S. Runberg and K.W. Thomas, 1984, Retardation of Radionuclides by Rock Units along the Path to the Accessible Environment, Materials Research Society, Symposium Proceedings, Scientific Basis for Nuclear Waste Management VII, v. 26. p. 329336.

Rozsa, R.B., D.F. Snoeberger and J. Baker, 1974, Chimney Permeability Data Analysis, Lawrence Livermore National Laboratory, UCID-16440.

Sawyer, D.A., R.J. Fleck, M.A. Lanphere, R.G. Warren, D.E. Broxton, M.R. Hudson, 1994, Episodic Caldera Volcanism in the Miocene Southwestern Nevada Volcanic Field: Revised Stratigraphic Framework, $40 \mathrm{Ar} /{ }^{39} \mathrm{Ar}$ Geochronology, and Implications for Magmatism and Extension, Geological Society of America Bulletin, v. 106, p. 1304-1318.

Short, D.W., D.J. Ruffner and L.J. Jardine, 1991, Engineered Barrier System and a Waste Package Design Concepts for a Potential Geologic Repository at Yucca Mountain, Lawrence Livermore National Laboratory, UCRL-JC-106916 Preprint.

Smith, D.K., 1993, A Review of Literature Pertaining to the Leaching and Sorption of Radionuclides Associated with Nuclear Explosive Melt Glasses, Lawrence Livermore National Laboratory, UCRL-ID-113370.

Smith, D.K., 1994, Characterization of Nuclear Explosive Melt Debris, Lawrence Livermore National Laboratory, UCRL-JC-119227 Preprint. Also in press, Radiochimica Acta.

Thomas, K.W., 1987, Summary of Sorption Measurements Performed With Yucca Mountain, Nevada Tuff Samples and water from the Well J-13, Los Alamos National Laboratory, LA-10960-MS, 99p.

Thompson, J.L., 1995a, Laboratory and Field Studies Related to the Hydrologic Resources Management Program, October 1, 1993 - September 30, 1994, Los Alamos National Laboratory, LA-12917-PR.

Thompson, J.L., 1995b, Radionuclide Distribution in a Nuclear Cavity: The Baseball Event, Los Alamos National Laboratory, LA-UR-95-744.

Triay, I.R., A.J. Mitchell and M.A. Ott, 1991, Radionuclide Migration as a Function of Mineralogy, High Level Radioactive Waste Management, Proceedings of the Second International Conference, America Society of Civil Engineers and American Nuclear Society, p. 494-498. 
U.S. Department of Energy, Nevada Operations Office, 1994, Regulatory Acceptance of Well Construction Techniques at the Nevada Test Site, Draft, DOE/NV-XXX, UC-700, Las Vegas, NV.

U.S. Department of Energy, Nevada Operations Office, 1995, Underground Test Area Operable Unit Work Plan, Nevada Test Site, Nevada, DOE/NV-389, UC-700, Las Vegas, NV.

Wagoner, J.L., 1987, Making Sense of the Mixed Alluvium in the Yucca Flat Basin, Proceedings of the Fourth Symposium on Containment of Underground Nuclear Explosions, Lawrence Livermore National Laboratory, CONF-870961, v. 2, Erratum, 23p. 